\title{
SMART CITY INDEX BASED ON TOPSIS METHOD
}

\author{
Adam SOJDA \\ Silesian University of Technology, Zabrze; adam.sojda@polsl.pl, ORCID: 0000-0002-3021-4451
}

Purpose: The construction of rankings is an important element of city assessment consistent with the Smart City concept. New rankings appear periodically. New sets of variables or concepts for ranking are proposed. The article is part of this trend.

Design/methodology/approach: The article combines the hierarchical structure of areas and indicators used in Smart City assessment with the concept of multidimensional assessment of facilities using the TOPSIS method.

Findings: Assessment of the possibility of using the presented method to evaluate both individual areas of the city operation combined with an overall assessment.

Originality/value: The most important achievement of this article is the proposal of the concept of city evaluation using the TOPSIS (SCI2T) method. An assessment of selected cities based on the proposed method is also presented.

Keywords: Smart City, TOPSIS method, linear ordering.

Category of the paper: Research paper.

\section{Introduction}

The (United Nations Report, 2018) report predicts that in 2050, 68\% of population will live in urban areas. In 2018, 82\% of population lives in urban areas in North America. In Europe, this number is $74 \%$. The forecast for Asia and Africa predicts rapid urbanization over the next three decades. Therefore, there is a growing need for proper city management and creating favourable living conditions for residents. In the near future, the Earth will change its face from rural to urban, creating new challenges for cities.

The concept of Smart City - an intelligent city is constantly developed. We are currently talking about Smart City 5.0. (Svítek et al., 2020). The idea of Smart City is multidimensional and goes beyond the concept of a smart city based only on technology. There are two trends in understanding the phenomenon of Smart City. The first is associated with the effective use of technology. Technology is used as a tool to create economic growth and human capital or to 
ensure higher efficiency of economic activities (Hollands, 2008). The second should be identified with the new paradigm determining the role, significance and development of the city (Giffinger et al., 2007). According to this concept, the development of the city should focus on human and social capital, the environment and education. One of the most complete definitions of Smart City was formulated in a report containing a ranking of smart cities (EC, 2007). Yet another concept defines Smart Cities as those that using technology, change the city into a human-friendly environment in aspects such as mobility, management and the environment (Bakıc1 et al., 2013).

Table 1.

Selected Smart City assessment systems

\begin{tabular}{|c|c|}
\hline Name & Description \\
\hline $\begin{array}{l}\text { European } \\
\text { Smart Cities } \\
\text { Ranking }\end{array}$ & $\begin{array}{l}\text { European ranking compiled by an international consortium chaired by the University of } \\
\text { Technology in Vienna. It includes, among others: Bydgoszcz, Gdańsk, Katowice, Kraków, } \\
\text { Łódź, Lublin, Poznań, Szczecin and Wrocław. } \\
\text { It consists of } 6 \text { categories and } 64 \text { indicators. } \\
\text { http://www.smart-cities.eu/ (accessed on: 09.04.2020) }\end{array}$ \\
\hline $\begin{array}{l}\text { The Smart } \\
\text { Cities Wheel }\end{array}$ & $\begin{array}{l}\text { A holistic assessment system, taking into account the key elements that make up a Smart City. } \\
\text { A tool to support city benchmarking. Compiled by Boyd Cohen, in collaboration with leading } \\
\text { cities around the world. } \\
\text { It includes } 6 \text { categories and } 62(28) \text { indicators. Boyd Cohen } \\
\text { https://www.fastcompany.com/1680538/what-exactly-is-a-smart-city } \\
\text { https://www.fastcompany.com/3038818/the-smartest-cities-in-the-world-2015-methodology } \\
\text { (accessed on: } 09.04 .2020)\end{array}$ \\
\hline $\begin{array}{l}\text { Bilbao Smart } \\
\text { Cities Study }\end{array}$ & $\begin{array}{l}\text { The idea initiated at the world summit in Bilbao, giving an overview of the situation in cities } \\
\text { of different regions of the world. Includes, among others, Katowice. } \\
\text { It consists of } 6 \text { categories and } 49 \text { indicators. } \\
\text { http://www.uclg-digitalcities.org/app/uploads/2015/06/en_smartcitiesstudy.pdf } \\
\text { (accessed on: } 09.04 .2020 \text { ) }\end{array}$ \\
\hline $\begin{array}{l}\text { Triple-helix } \\
\text { network } \\
\text { model } \\
\text { for smart cities } \\
\text { performance }\end{array}$ & $\begin{array}{l}\text { Model analysing the links between smart city components, including social relations. It uses } \\
\text { a modified triple helix model applied in innovation analysis. } \\
\text { It consists of } 5 \text { categories and } 45 \text { indicators. } \\
\text { http://degree.ubvu.vu.nl/repec/vua/wpaper/pdf/20110045.pdf } \\
\text { (accessed on: } 09.04 .2020 \text { ) }\end{array}$ \\
\hline $\begin{array}{l}\text { Smart City } \\
\text { PROFILES }\end{array}$ & $\begin{array}{l}\text { A set of } 21 \text { Smart City indicators, with particular emphasis on climate change and energy } \\
\text { efficiency. Indicators include 5 categories. Smart City PROFILES (2013) } \\
\text { https://www.smartcities.at/assets/03-Begleitmassnahmen/SmartCity-PDF-INTRO.pdf } \\
\text { (accessed on: } 10.04 .2020)\end{array}$ \\
\hline CITYkeys & $\begin{array}{l}\text { An EU project (under the } \mathrm{H} 2020 \text { program) aimed at providing a validated, holistic framework } \\
\text { for measuring and assessing Smart Cities. Also in the context of city and project } \\
\text { implementation. It consists of } 73 \text { indicators in } 5 \text { main categories. } \\
\text { http://www.citykeys-project.eu/ } \\
\text { (accessed on: } 10.04 .2020 \text { ) }\end{array}$ \\
\hline $\begin{array}{l}\text { CIMI (City } \\
\text { In Motion } \\
\text { Index), IESE } \\
\text { Cities in } \\
\text { Motion Index }\end{array}$ & $\begin{array}{l}\text { Project implemented by the Business School University of Navarra. } 10 \text { key assessment areas } \\
\text { and } 96 \text { indicators are considered. The concept is being developed. In 2019, } 13 \text { more indicators } \\
\text { are considered than in the previous year. Of the } 174 \text { cities evaluated, there are } 2 \text { Polish cities: } \\
\text { Warsaw and Wroclaw. } \\
\text { https://media.iese.edu/research/pdfs/ST-0509-E.pdf (accessed on: 10.04.2020) DOI: } \\
\text { https://dx.doi.org/10.15581/018.ST-509 }\end{array}$ \\
\hline
\end{tabular}

Source: Compiled on the basis of: (Ahvenniemi et al., 2017; Giffinger et al., 2007; Lombardi et al., 2011; Boasberg et al., 2019). 
The selection of appropriate indicators (Lombardi et al., 2011; Szczech-Pietkiewicz, 2015) to describe a city as a Smart City is of key importance for its assessment. The variety of emerging rankings means that the problem of choosing indicators is still valid (Huovila et al., 2017; Aletà et al., 2017; Boasberg et al., 2019; Bosch et al., 2017).

The categories, areas in which we perceive Smart Cities include: smart economy ECO, intelligent population $\mathrm{PEO}$, smart management GOV, intelligent mobility MOB, intelligent environment ENV, intelligent living conditions LIV.

The construction and ranking of smart cities is time consuming, as relevant data must be collected. Access to a reliable data source is very important. The EUROSTAT database should be considered a reliable source of data. This database resources include an area related to Urban Audit urban areas (Szczech-Pietkiewicz, 2015; Sojda, 2018).

\section{Data and Methods}

\subsection{Data}

Analysis data comes from the Eurostat database. The database includes the 1990-2019 information about 1,822 cities from 32 countries. There were 572 indicators used to distinguish the cities. Most of them are objective. Indicators that refer to the residents' feedback are especially valuable. In most cases, a five-point Likert scale was used or the percentage of matching answers was provided.

For data expressed on the Likert scale, switching to one synthetic indicator using the following weight system was suggested. Weights $(-2 ;-1 ; 0 ; 1 ; 2)$ are assigned to the response: (strongly disagree, very unsatisfied; somewhat disagree, rather unsatisfied; do not know/no answer, somewhat agree, rather satisfied; strongly agree, very satisfied).

Variables and indicators are expressed in different units, which assume values of various orders of magnitude. In order to allow comparison of these quantities, a standardization process was performed (Kukuła, 2012; Sojda, \& Wolny, 2020).

Table 2.

Indicators in ranking

\begin{tabular}{|c|c|c|c|}
\hline INDIC & NAME & MD & SD \\
\hline ECO O1 & Activity rate & 1 & $\mathrm{~S}$ \\
\hline ECO O2 & All companies per 1000 population & 2 & $\mathrm{~S}$ \\
\hline ECO O3 & Unemployment rate & 0 & $\mathrm{D}$ \\
\hline ECO S1 & In this city, it is easy to find a good job & 0 & $\mathrm{~S}$ \\
\hline ECO S2 & Most important in my city: Unemployment & 0 & $\mathrm{D}$ \\
\hline ECO S3 & You have difficulty paying your bills at the end of the month & 0 & $\mathrm{D}$ \\
\hline ENV O1 & Annual average concentration of $\mathrm{NO} 2\left(\mu \mathrm{g} / \mathrm{m}^{3}\right)$ & 0 & $\mathrm{D}$ \\
\hline ENV O2 & Annual average concentration of PM10 $\left(\mu \mathrm{g} / \mathrm{m}^{3}\right)$ & 1 & $\mathrm{D}$ \\
\hline ENV O3 & Number of days particulate matter PM10 concentrations exceed $50 \mu \mathrm{g} / \mathrm{m}^{3}$ & 0 & $\mathrm{D}$ \\
\hline
\end{tabular}


Cont. table 2.

\begin{tabular}{|l|l|c|c|}
\hline ENV S1 & Most important in my city: air pollution & 0 & $\mathrm{D}$ \\
\hline ENV S2 & The cleanliness in the city & 0 & $\mathrm{~S}$ \\
\hline ENV S3 & $\begin{array}{l}\text { This city is committed to the fight against climate change (e.g.; reducing energy } \\
\text { consumption in housing or promoting alternatives to transport by car) }\end{array}$ & 0 & $\mathrm{~S}$ \\
\hline PEO O1 & $\begin{array}{l}\text { Employment (jobs) in professional, scientific and technical activities; } \\
\text { administrative and support service activities (NACE Rev. 2, M and N) }\end{array}$ & 0 & $\mathrm{~S}$ \\
\hline PEO O2 & Median population age & 3 & $\mathrm{D}$ \\
\hline PEO O3 & $\begin{array}{l}\text { Proportion of population aged 25-64 qualified at level 5 to 8 ISCED, from 2014 } \\
\text { onwards }\end{array}$ & 2 & $\mathrm{~S}$ \\
\hline PEO S1 & Foreigners who live in this city are well integrated & 0 & $\mathrm{~S}$ \\
\hline PEO S2 & Most people in my neighbourhood can be trusted & 0 & $\mathrm{~S}$ \\
\hline PEO S3 & Schools in the city & 0 & $\mathrm{~S}$ \\
\hline LIV O1 & Infant mortality rate (per 1000 live births) & 0 & $\mathrm{D}$ \\
\hline LIV O2 & $\begin{array}{l}\text { Number of deaths per year under 65 due to diseases of the circulatory or respiratory } \\
\text { systems per 1000 population }\end{array}$ & 0 & $\mathrm{D}$ \\
\hline LIV O3 & Number of murders and violent deaths per 1000 population & 8 & $\mathrm{D}$ \\
\hline LIV S1 & Health care services offered by doctors and hospitals in this city & 0 & $\mathrm{~S}$ \\
\hline LIV S2 & Most important in my city: social services & 0 & $\mathrm{D}$ \\
\hline LIV S3 & You feel safe in this city & 0 & $\mathrm{~S}$ \\
\hline MOB O1 & $\begin{array}{l}\text { Cost of a combined monthly ticket (all modes of public transport) for 5-10 km in } \\
\text { the central zone - EUR }\end{array}$ & 2 & $\mathrm{D}$ \\
\hline MOB O2 & Number of registered cars per 1000 population & 3 & $\mathrm{~S}$ \\
\hline MOB O3 & Share of journeys to work by public transport (rail, metro, bus, tram) - \% & 8 & $\mathrm{~S}$ \\
\hline MOB S1 & Means of transport primarily used to go to work/training place: public transport & 0 & $\mathrm{~S}$ \\
\hline MOB S2 & Most important in my city: public transport & 0 & $\mathrm{D}$ \\
\hline MOB S3 & Public transport in the city, for example bus, tram or metro & 0 & $\mathrm{~S}$ \\
\hline
\end{tabular}

The selection of indicators also included country capitals. Due to missing data in the database, not all European capitals are represented in the study. The following missing data imputation procedure was used. The lack of data was supplemented by the last value found in the database. If the value did not exist and the city was described by most indicators (with no fewer than three missing), the worst value of the other objects - cities was assigned.

The indicators were standardized and then converted into stimulants. An increase in the value of the indicator is responsible for an ordered increase in the value of the phenomenon.

The MD column shows how many values of the variable had to be supplemented with the minimum value. The SD column shows whether the indicator is considered to be a stimulant (S) or a destimulant (D).

Table 3.

Cities in ranking

\begin{tabular}{|c|c|c|}
\hline CAPITAL & MD & POPULATION \\
\hline Vienna & 2 & $1,766,746$ \\
\hline Brussels & 0 & $1,205,492$ \\
\hline Sofia & 0 & $1,238,438$ \\
\hline Prague & 2 & $1,324,277$ \\
\hline Berlin & 0 & $3,613,495$ \\
\hline Copenhagen & 0 & 559,440 \\
\hline Tallinn & 0 & 430,805 \\
\hline Athens & 3 & 664,046 \\
\hline Madrid & 1 & $3,223,334$ \\
\hline Paris & 0 & $9,803,494$ \\
\hline
\end{tabular}


Cont. table 3.

\begin{tabular}{|c|c|c|}
\hline Helsinki & 0 & 643,272 \\
\hline Budapest & 2 & $1,749,734$ \\
\hline Dublin & 2 & 516,255 \\
\hline Rome & 1 & $2,872,800$ \\
\hline London & 2 & $8,866,541$ \\
\hline Vilnius & 0 & 547,484 \\
\hline Luxembourg & 2 & 115,227 \\
\hline Riga & 0 & 632,479 \\
\hline Amsterdam & 0 & 960,402 \\
\hline Oslo & 0 & 623,966 \\
\hline Warsaw & 3 & $1,735,442$ \\
\hline Lisbon & 1 & 507,220 \\
\hline Bucharest & 4 & $2,131,034$ \\
\hline Stockholm & 0 & 949,761 \\
\hline Ljubljana & 0 & 288,919 \\
\hline Bratislava & 1 & 432,864 \\
\hline Zagreb & 4 & 804,049 \\
\hline & &
\end{tabular}

Basic statistical parameters were determined for the transformed variables.

Table 4.

Statistical parameters of indicators after standardisation

\begin{tabular}{|c|c|c|c|c|c|c|c|}
\hline INDIC & Range & IQR & Quartile 1 & Quartile 2 & Quartile 3 & Skewness & Kurtosis \\
\hline ECO O1 & 3.46 & 1.57 & -0.85 & 0.08 & 0.72 & -0.20 & -0.97 \\
\hline ECO O2 & 3.94 & 1.20 & -0.62 & -0.14 & 0.58 & 0.39 & 0.02 \\
\hline ECO O3 & 3.93 & 1.33 & -0.67 & 0.18 & 0.66 & -0.61 & -0.12 \\
\hline ECO S1 & 3.72 & 1.33 & -0.58 & 0.26 & 0.76 & -0.79 & -0.32 \\
\hline ECO S2 & 3.63 & 1.37 & -0.50 & -0.06 & 0.87 & -0.56 & -0.06 \\
\hline ECO S3 & 4.11 & 1.39 & -0.76 & -0.08 & 0.63 & 0.70 & 0.42 \\
\hline ENV O1 & 3.95 & 1.31 & -0.71 & 0.22 & 0.60 & -0.49 & -0.17 \\
\hline ENV O2 & 3.79 & 0.86 & -0.29 & 0.12 & 0.57 & -0.94 & 0.82 \\
\hline ENV O3 & 3.96 & 1.07 & -0.31 & 0.25 & 0.77 & -1.64 & 2.65 \\
\hline ENV S1 & 3.68 & 1.06 & -0.34 & 0.02 & 0.71 & -0.80 & 0.06 \\
\hline ENV S2 & 4.02 & 1.62 & -0.86 & 0.19 & 0.76 & -0.18 & -0.66 \\
\hline ENV S3 & 3.49 & 1.36 & -0.63 & 0.09 & 0.73 & -0.05 & -0.88 \\
\hline PEO O1 & 3.58 & 0.88 & -0.67 & -0.40 & 0.20 & 1.66 & 1.90 \\
\hline PEO O2 & 3.56 & 0.99 & -0.35 & -0.06 & 0.64 & -0.33 & -0.34 \\
\hline PEO O3 & 4.14 & 1.07 & -0.36 & 0.09 & 0.71 & -0.33 & 0.23 \\
\hline PEO S1 & 4.53 & 1.25 & -0.46 & -0.07 & 0.79 & -0.60 & 0.90 \\
\hline PEO S2 & 3.50 & 1.25 & -0.58 & -0.02 & 0.67 & 0.08 & -0.80 \\
\hline PEO S3 & 3.18 & 1.81 & -1.02 & 0.08 & 0.79 & 0.00 & -1.30 \\
\hline LIV O1 & 4.90 & 1.06 & -0.42 & 0.14 & 0.64 & -1.94 & 6.48 \\
\hline LIV O2 & 4.57 & 0.42 & 0.08 & 0.38 & 0.49 & -3.02 & 10.16 \\
\hline LIV O3 & 2.45 & 2.11 & -1.33 & 0.42 & 0.78 & -0.51 & -1.58 \\
\hline LIV S1 & 3.09 & 1.81 & -0.90 & -0.02 & 0.91 & -0.16 & -1.36 \\
\hline LIV S2 & 3.74 & 1.43 & -0.69 & 0.20 & 0.73 & -0.16 & -0.81 \\
\hline LIV S3 & 3.57 & 1.40 & -0.57 & 0.07 & 0.83 & -0.71 & -0.02 \\
\hline MOB O1 & 3.23 & 1.28 & -0.43 & -0.08 & 0.85 & -0.60 & -0.45 \\
\hline MOB O2 & 3.42 & 1.10 & -0.72 & -0.08 & 0.38 & 0.64 & -0.28 \\
\hline MOB O3 & 4.07 & 1.69 & -1.10 & 0.06 & 0.59 & 0.81 & 1.30 \\
\hline MOB S1 & 3.76 & 1.65 & -0.84 & 0.04 & 0.81 & 0.11 & -0.81 \\
\hline MOB S2 & 3.89 & 1.42 & -0.59 & 0.02 & 0.83 & -0.49 & -0.34 \\
\hline MOB S3 & 4.99 & 0.85 & -0.32 & 0.14 & 0.53 & -0.91 & 2.27 \\
\hline
\end{tabular}


The values of the statistical parameters indicate the differentiation between variables. There is no variable that could unambiguously distort the results of the ranking. Variables can be considered as appropriately selected.

\subsection{Methods}

The TOPSIS method was proposed to build the ranking (Yoon, \& Hwang, 1995; Li et al., 2020; Gutiérrez et al., 2020).

We assume that we have to evaluate $m$ objects described by $n$ variables. First, a standardization procedure is carried out. For the stimulant, the variable is determined by the formula (1) and for the destimulant by the formula (2)

$$
\begin{aligned}
& z_{i j}=\frac{x_{i j}-\bar{x}_{j}}{s_{j}} \\
& z_{i j}=-\frac{x_{i j}-\bar{x}_{j}}{s_{j}}
\end{aligned}
$$

where:

$x_{i j}$ - observation of the $j$-th indicator, for the $i$-th object,

$\bar{x}_{j}-$ the average value for $j$-th indicator,

$s_{j}-$ standard deviation value for $j$-th indicator.

\section{TOPSIS method}

The TOPSIS method uses two reference points (pattern and anti-pattern) in relation to which the object distance is determined.

Step 1 - Determination of the pattern (3) and anti-pattern (4).

$$
\begin{aligned}
& z_{0 j}^{+}=\max \left\{z_{i j}\right\} \\
& z_{0 j}^{-}=\min \left\{z_{i j}\right\}
\end{aligned}
$$

Step 2 - Determination of distance from the pattern (5) and anti-pattern (6).

$$
\begin{aligned}
& d_{0 i}^{+}=\sqrt{\sum_{j}\left(z_{0 j}^{+}-z_{i j}\right)^{2}} \\
& d_{0 i}^{-}=\sqrt{\sum_{j}\left(z_{0 j}^{-}-z_{i j}\right)^{2}}
\end{aligned}
$$

Step 3 - Determining the aggregate variable value (7).

$$
q_{\mathrm{i}}=\frac{d_{0 i}^{-}}{d_{0 i}^{-}+d_{0 i}^{+}}
$$

In the TOPSIS method, the higher the values of the aggregated variable, the better the object. 


\section{Smart City TOPSIS (SCI2T) Index}

The higher the values of the aggregated variable, the better the object.

$$
\mathrm{SCI} 2 \mathrm{~T}=\text { TOPSIS }\left(I_{\text {TOPSIS }_{i}}\right)
$$

for the area

$$
I_{\text {TOPSIS }_{i}}=\operatorname{TOPSIS}\left(\left\{I_{i j}\right\}\right)
$$

where

$I_{i j}$ - value of the $j$-th variable, a measure included in the $i$-th area,

TOPSIS() - application of the TOPSIS method to a group of indicators describing the objects, $I_{\text {TOPSIS }_{i}}$ - aggregate variable values for the $i$-th area.

The TOPSIS method is used twice to determine the ranking. It is used the first time for footnotes for specific area indicators. The second time, for the aggregated values obtained in individual areas.

\section{Results and discussion}

Based on the proposed method and TOPSIS, the following city ranking was obtained.

Table 5.

Ranking results

\begin{tabular}{|c|c|c|c|c|c|c|c|}
\hline CAPITAL & SCI2T: & ECO & ENV & PEO & LIV & MOB & TOPSIS \\
\hline Helsinki & 1 & 12 & 2 & 8 & 4 & 12 & 2 \\
\hline Stockholm & 2 & 11 & 3 & 9 & 2 & 22 & 4 \\
\hline Tallinn & 3 & 3 & 1 & 12 & 13 & 6 & 1 \\
\hline Oslo & 4 & 7 & 13 & 2 & 1 & 18 & 3 \\
\hline Copenhagen & 5 & 17 & 6 & 6 & 3 & 23 & 9 \\
\hline Amsterdam & 6 & 9 & 9 & 7 & 10 & 13 & 5 \\
\hline Vilnius & 7 & 1 & 5 & 5 & 23 & 20 & 6 \\
\hline Luxembourg & 8 & 20 & 7 & 4 & 15 & 8 & 8 \\
\hline London & 9 & 8 & 12 & 18 & 5 & 15 & 10 \\
\hline Dublin & 10 & 21 & 8 & 3 & 11 & 24 & 11 \\
\hline Vienna & 11 & 19 & 4 & 21 & 17 & 4 & 12 \\
\hline Prague & 12 & 2 & 19 & 15 & 16 & 2 & 7 \\
\hline Berlin & 13 & 16 & 11 & 25 & 9 & 9 & 13 \\
\hline Ljubljana & 14 & 26 & 10 & 1 & 26 & 16 & 15 \\
\hline Riga & 15 & 5 & 14 & 23 & 20 & 19 & 17 \\
\hline Paris & 16 & 14 & 23 & 11 & 6 & 5 & 14 \\
\hline Brussels & 17 & 22 & 16 & 14 & 7 & 17 & 18 \\
\hline Warsaw & 18 & 13 & 18 & 16 & 18 & 7 & 16 \\
\hline Bratislava & 19 & 6 & 17 & 24 & 22 & 10 & 19 \\
\hline Budapest & 20 & 10 & 21 & 13 & 24 & 11 & 20 \\
\hline Lisbon & 21 & 15 & 15 & 20 & 12 & 27 & 23 \\
\hline Madrid & 22 & 27 & 20 & 19 & 8 & 3 & 22 \\
\hline
\end{tabular}


Cont. table 5.

\begin{tabular}{|c|c|c|c|c|c|c|c|}
\hline Sofia & 23 & 4 & 25 & 17 & 21 & 1 & 21 \\
\hline Zagreb & 24 & 25 & 22 & 10 & 19 & 21 & 24 \\
\hline Rome & 25 & 24 & 24 & 27 & 14 & 26 & 25 \\
\hline Bucharest & 26 & 18 & 27 & 22 & 27 & 25 & 27 \\
\hline Athens & 27 & 23 & 26 & 26 & 25 & 14 & 26 \\
\hline
\end{tabular}

The method allows assessment of the city within each of the defined areas plus an overall assessment. The high position of Scandinavian cities is associated with a high rating in areas related to living conditions and the natural environment. Tallinn, in the third place on the ranking list, also owes its position to two areas in which it received high ratings. The relatively low position of the cities hitherto considered to be leaders may be caused by the inclusion of subjective ranking measures. The smaller the city, the smaller the problems of its inhabitants may seem. Possible problems are easier to solve. Cultural differences may also cause that this group of cities with a similar geographical location achieved a similar result.

The analysis of the differences between the rankings and the SCI2T ranking shows that there are no fundamental differences between the presented new ranking method and the general TOPSIS method. The maximum shift in the ranking is 5 places.

Table 6.

Ranking results - comparison to SCI2T results

\begin{tabular}{|c|c|c|c|c|c|c|}
\hline CAPITAL & ECO & ENV & PEO & LIV & MOB & TOPSIS \\
\hline Helsinki & -11 & -1 & -7 & -3 & -11 & -1 \\
\hline Stockholm & -9 & -1 & -7 & 0 & -20 & -2 \\
\hline Tallinn & 0 & 2 & -9 & -10 & -3 & 2 \\
\hline Oslo & -3 & -9 & 2 & 3 & -14 & 1 \\
\hline Copenhagen & -12 & -1 & -1 & 2 & -18 & -4 \\
\hline Amsterdam & -3 & -3 & -1 & -4 & -7 & 1 \\
\hline Vilnius & 6 & 2 & 2 & -16 & -13 & 1 \\
\hline Luxembourg & -12 & 1 & 4 & -7 & 0 & 0 \\
\hline London & 1 & -3 & -9 & 4 & -6 & -1 \\
\hline Dublin & -11 & 2 & 7 & -1 & -14 & -1 \\
\hline Vienna & -8 & 7 & -10 & -6 & 7 & -1 \\
\hline Prague & 10 & -7 & -3 & -4 & 10 & 5 \\
\hline Berlin & -3 & 2 & -12 & 4 & 4 & 0 \\
\hline Ljubljana & -12 & 4 & 13 & -12 & -2 & -1 \\
\hline Riga & 10 & 1 & -8 & -5 & -4 & -2 \\
\hline Paris & 2 & -7 & 5 & 10 & 11 & 2 \\
\hline Brussels & -5 & 1 & 3 & 10 & 0 & -1 \\
\hline Warsaw & 5 & 0 & 2 & 0 & 11 & 2 \\
\hline Bratislava & 13 & 2 & -5 & -3 & 9 & 0 \\
\hline Budapest & 10 & -1 & 7 & -4 & 9 & 0 \\
\hline Lisbon & 6 & 6 & 1 & 9 & -6 & -2 \\
\hline Madrid & -5 & 2 & 3 & 14 & 19 & 0 \\
\hline Sofia & 19 & -2 & 6 & 2 & 22 & 2 \\
\hline Zagreb & -1 & 2 & 14 & 5 & 3 & 0 \\
\hline Rome & 1 & 1 & -2 & 11 & -1 & 0 \\
\hline Bucharest & 8 & -1 & 4 & -1 & 1 & -1 \\
\hline Athens & 4 & 1 & 1 & 2 & 13 & 1 \\
\hline
\end{tabular}


There are clear differences between the overall rating and the ratings in individual areas. The differences cover even 22 places in the rankings.

Table 7.

Pearson's linear correlation coefficients between values and ranks

\begin{tabular}{cccccccc}
\hline & SCI2T: & ECO & ENV & PEO & LIV & MOB & TOPSIS \\
\hline SCI2T: & & $0.42^{*}$ & $0.90^{*}$ & $0.63^{*}$ & $0.59^{*}$ & 0.04 & $0.98^{*}$ \\
ECO & $0.49^{*}$ & & 0.22 & 0.06 & 0.02 & 0.24 & $0.50^{*}$ \\
ENV & $0.83^{*}$ & 0.18 & & $0.52^{*}$ & $0.42^{*}$ & -0.04 & $0.83^{*}$ \\
PEO & $0.66^{*}$ & 0.13 & $0.49^{*}$ & & 0.28 & -0.10 & $0.63^{*}$ \\
LIV & $0.61^{*}$ & 0.06 & $0.50^{*}$ & 0.27 & & -0.06 & $0.54^{*}$ \\
MOB & 0.32 & 0.22 & -0.01 & 0.09 & -0.07 & & 0.18 \\
TOPSIS & $0.98^{*}$ & $0.41^{*}$ & $0.89^{*}$ & $0.69^{*}$ & $0.64^{*}$ & 0.19 & \\
\hline
\end{tabular}

* Significant correlation at 0.05 (bilateral).

Table 7 presents Pearson's linear correlation coefficients between the rankings obtained (values below the main diagonal) and the values of the relevant aggregates (values above the main diagonal). SCI2T and TOPSIS rankings show the strongest mutual correlation. The positions in the ranking differ the least from all analysed. The position in the ranking is most strongly influenced by the position in the ENV area. PEO and LIV area-related positions show comparable effects. The next areas in order of impact are ECO and MOB.

\section{Conclusion}

The proposed concept of determining the city ranking not only allows the assessment of the city but also its assessment in individual areas. Therefore, it is a better proposition than the basic TOPSIS method. Interestingly, Scandinavian capitals are positioned in the best places. On the one hand, we should remember that the assessment was built based on the residents' survey results. It is possible that the impact of these assessments should be limited by introducing the possibility of including weights in the method. At the moment, the method is consistent with the weights for sustainable development, where their equality is assumed. Further work should focus on the possibility of introducing weights and showing their impact on the ranking order. Determining the impact on the ranking of subjective ratings will be significant. 


\section{References}

1. Ahvenniemi, H., Huovila, A., Pinto-Seppä, I., \& Airaksinen, M. (2017). What are the differences between sustainable and smart cities? Cities. https://doi.org/ 10.1016/ j.cities.2016.09.009.

2. Aletà, N.B., Alonso, C.M., \& Ruiz, R.M.A. (2017). Smart Mobility and Smart Environment in the Spanish cities. Transportation Research Procedia. https://doi.org/10.1016/ j.trpro.2017.05.084.

3. Bakıc1, T., Almirall, E., \& Wareham, J. (2013). A Smart City Initiative: the Case of Barcelona. Journal of the Knowledge Economy, 4(2), 135-148. https://doi.org/ 10.1007/ s13132-012-0084-9.

5. EC (n.a.) (2007). Smart cities: ranking of European mid-sized cities. Digital Agenda for Europe, October, 28. https://doi.org/10.1016/S0264-2751(98)00050-X.

7. Hollands, R.G. (2008). Will the real smart city please stand up? Intelligent, progressive or entrepreneurial? City, 12(3), 303-320. https://doi.org/10.1080/13604810802479126.

9. Kukuła, K. (2012). Propozycja budowy rankingu obiektów z wykorzystaniem cech ilościowych oraz jakościowych. Metody Ilościowe w Badaniach Ekonomicznych.

11. Lombardi, P., Giordano, S., Caragliu, A., Del Bo, C., Deakin, M., Nijkamp, P., Kourtit, K., \& Farouh, H. (2011). An Advanced Triple-Helix Network Model for Smart Cities Performance. https://doi.org/10.4018/978-1-61350-453-6.ch004.

13. Sojda, A., \& Wolny, M. (2020). The impact of standardisation method on Smart City ranking. Scientific Papers of Silesian University of Technology. Organization and Management Series. https://doi.org/10.29119/1641-3466.2020.142.6.

15. Szczech-Pietkiewicz, E. (2015). Smart city - próba definicji i pomiaru. Prace Naukowe Uniwersytetu Ekonomicznego We Wrocławiu, 391. https://doi.org/10.15611/pn. 2015.391.07. 